\title{
Kultura obywatelska w społeczeństwie konsumpcyjnym
}

DOI 10.35757/CIV.2016.18.06

\section{Wstęp}

Na zagadnienie kultury możemy spojrzeć paralelnie jak na etykę, każda kultura bowiem zawiera w sobie pewien system etyczny. W filozofii dokonujemy rozróżnienia na etykę opisową i normatywna, tak samo da się potraktować zjawisko kultury. Możemy opisać kulturę danej jednostki, społeczności, społeczeństwa czy też narodu bądź też podchodzić do niej w sposób normatywny, czyli dokonywać jej oceny $z$ jakiejś perspektywy. W naukach humanistyczno-społecznych występuje różnorodność definiowania i opisywania tego, co rozumie się pod pojęciem „kultury”. Najogólniej kategorię kultury traktuje się jako zespół orientacji, wartości, norm i celów podzielanych przez ludzi i wytworzonych w długotrwałych procesach społecznych interakcji.

Właściwie jedynie osoby dysponujące poglądami nihilistycznymi postrzegaja kulture jednoznacznie negatywnie, jako istotny

Krzysztof Przybyszewski - doktor habilitowany, profesor nadzwyczajny w Zakładzie Filozofii Społecznej i Politycznej Instytutu Filozofii Uniwersytetu im. A. Mickiewicza w Poznaniu. Autor monografii Prawa człowieka $w$ kontekstach kulturowych, Wydawnictwo Naukowe Instytutu Filozofii UAM, Poznań 2010, ss. 263 oraz Kultura publiczna. Refleksje wokół kondycji społeczeństwa i państwa polskiego, Wydawnictwo Naukowe Instytutu Filozofii UAM, Poznań 2013, ss. 420. Absolwent Szkoły Praw Człowieka Helsińskiej Fundacji Praw Człowieka. Swoje zainteresowania badawcze koncentruje wokół filozofii społecznej i politycznej, antropologii filozoficznej, aksjologii polityki, praw człowieka, filozofii prawa, etyki, medioznawstwa oraz filozofii praktycznej. 
hamulec w rozwoju indywiduum („nadczłowieka”), w pozostałych nurtach, trendach myślowych podkreśla się jej znacząca rolę dla rozwoju człowieka, czy też takiej lub innej wspólnoty (np. politycznej bądź religijnej), a wskazuje się tylko pewne jej elementy, mogace stanowić pewna przeszkodę w rozwoju jednostki w owej kulturze żyjącej bądź społeczności w niej funkcjonującej. Ogólnie rzecz biorac, kultura jest ujmowana jako zjawisko pozytywne, niezbędne człowiekowi do życia, gdyż dzięki niej zyskuje on poczucie bezpieczeństwa ontologicznego ${ }^{1}$, jako że pozwala ona mu określić własną tożsamość dzięki uczestnictwu w życiu społecznym.

Truizmem jest stwierdzenie, że współczesna kultura zachodnia oparła życie społeczno-polityczne na wywodzącej się $z$ antyku idei obywatelskości. Idea ta jednak na przestrzeni dziejów podlegała różnym modyfikacjom, a w ich obrębie pojawiły się różne koncepcje obywatela. W naszym kręgu kulturowym najczęściej odwołujemy się do dwóch ujęć: republikańskiego, wywiedzionego z myśli Arystotelesa, oraz liberalnego, wyrastającego przede wszystkim z myśli Johna Locke'a. W obu tych koncepcjach obywatel ma stanowić spoiwo pomiędzy wymiarem indywidualistycznym (jednostka) a kolektywnym (wspólnota). Koncepcja republikańska bardziej przywiazuje wage do wspólnoty, liberalna zaś - do jednostki. Mimo to w obu ujęciach uznaje się, że cel i sens bycia obywatelem polega na aktywnym udziale $\mathrm{w} \dot{z}$ yciu publicznym. Chociaż owa aktywność wiąże się $z$ autonomia sprawcza obywatela, to jego partycypacja w życiu publicznym jest w obu koncepcjach dookreślana inaczej. W tradycji liberalnej i republikańskiej znajdziemy również odmienne konceptualizacje tego, co nazywamy społeczeństwem obywatelskim.

Cel niniejszego artykułu jednak nie sprowadza się do analizy i porównywania ze soba wspomnianych dwóch koncepcji obywatelstwa_oraz wynikających $z$ nich odmiennych wizji społeczeństwa

\footnotetext{
1 Bezpieczeństwo ontologiczne to pojęcie wprowadzone przez A. Giddensa, które oznacza: „zaufanie, wiarę, że świat materialny i społeczny, łącznie z podstawowymi parametrami jaźni i tożsamości społecznej sa takie jakie się jawia”. (Por. A. Giddens, Stanowienie społeczeństwa. Zarys teorii strukturacji, Wydawnictwo Zysk, Poznań 2003, s. 424.).
} 
obywatelskiego. W filozofii polityki zagadnienie to było już omawiane na wiele różnych sposobów i doprowadziło do wykrystalizowania się różnych wariantów obywatelstwa, czy to republikańskiego, czy liberalnego ${ }^{2}$. W niniejszym artykule zamierzamy raczej podjąć refleksję nad kultura polityczna, a zwłaszcza nad kultura obywatelska, w obliczu coraz większego wpływu „neoliberalnego programu” na model obywatela. „Program” ten przyczynia się do coraz silniejszego wyzbywania się przez obywateli ich kompetencji do troski o dobro ogółu, wspólnoty, prowadząc aż do pełnej ich alienacji ze sfery życia publicznego.

Formułowany jest tu pogląd, iż konsumpcjonizm kształtujący współczesne społeczeństwa „produkuje nihilistów politycznych”. Powstaje zatem pytanie, któż to taki ten nihilista polityczny. Najlepiej przedstawił to Szymon Wróbel w artykule, którego obszerny fragment przytoczymy, gdyż niezwykle trafnie i obrazowo charakteryzuje to pojęcie: „Nihilista politycznym jest Fryderyk Nietzsche, który krytykuje zastana kulturę liberalna jako wyzuta $z$ heroicznych cnót. Nihilista politycznym jest jednak także Adolf Hitler, który nie opiera swojego działania na myśleniu, ale na podejmowaniu krwawych decyzji. Nihilista politycznym jest ten, kto nie wierzy w cywilizację $z$ jej dwoma filarami - nauka i moralnością, a w szczególności ten, kto nie wierzy w uniwersalne zasady cywilizacyjne. Nihilista politycznym jest także ten, kto wyznaje ideę społeczeństwa otwartego, która roztrwania żywioł cnót w żywiole komercji i handlu. Zamknięcie się w obrębie własnej cywilizacji wytwarza groźbę nihilizmu, albowiem tracimy zdolność do uczenia się od innych cywilizacji, tracimy wrażliwość. Otwarcie się na inne cywilizacje wytwarza jednak także groźbę nihilizmu, albowiem zaczyna skutkować podejrzeniami i nieufnością wobec własnej cywilizacji - nasza wrażliwość na innych jest tak potężna, że nie jesteśmy już wstanie czerpać dumy z tego czym jesteśmy”3. Innymi

2 Por. D. Pietrzyk-Reeves: Idea społeczeństwa obywatelskiego, Wydawnictwo Naukowe Uniwersytetu Mikołaja Kopernika, Torun 2012.

3 S. Wróbel: Nihilizm polityczny, „Przegląd Polityczny” 2011, nr 107, s. 26. 
słowy, uważamy, że dominacja liberalnej polityki we współczesnym świecie, „produkując” nihilistów politycznych, niszczy szeroko rozumiana kulturę obywatelska, zarówno odpowiadajaca myśli republikańskiej, jak i tej liberalnej, szczególnie w jej wydaniu klasycznym. Tworzy bowiem świat bez polityki, bez aktywnych obywateli w sferze życia politycznego, sprowadzajac władzę państwowa do roli efektywnej administracji, samoregulowanego rynku, życia społecznego rozumianego jako gigantyczny sektor prywatny oraz jednostkowych strategii życiowych ${ }^{4}$. Mówi się w związku $z$ powyższym, iż zaczynamy żyć w świecie postpolityki ${ }^{5}$, to znaczy $\mathrm{w}$ takim świecie, gdzie podmiotowość polityczna obywatela traci na znaczeniu, bo promuje się jego działalność w sferze prywatnej, a nie publicznej. Oględnie rzecz ujmujacc, członek społeczeństwa, zamiast być dobrym obywatelem, ma być po prostu "dobrym" konsumentem, czyli takim, który nabywa, nie zadając zbędnych pytań. Proces wycofywania się obywatela $z$ działalności w sferze publicznej osłabia kulturę polityczna, a także powoduje zanikanie kultury obywatelskiej.

\section{Kompetentny obywatel jako warunek istnienia kultury obywatelskiej}

W potocznym rozumieniu termin „kultura polityczna” oznacza dobre maniery $\mathrm{w}$ procesie dochodzenia do decyzji politycznych. Niemniej w naukach humanistyczno-społecznych kulturę polityczna traktuje się jako kategorię analityczna służącą do badania kondycji danego społeczeństwa i państwa ${ }^{6}$. Przełom w studiach nad

\footnotetext{
4 N. Gładziuk: Polityka jako współżycie $z$ wrogiem. Rodowody koncepcji liberalnej, w: W. Wesołowski (red.): Koncepcje polityki, Wydawnictwo Naukowe Scholar, Warszawa 2009, s. 63.

5 Por. J. Golinowski: Perspektywa porzadku postpolitycznego. W stronę technologii władzy, Oficyna Wydawnicza Aspra-JR, Warszawa 2007.

${ }_{6}$ Por. K. Przybyszewski: Kultura publiczna. Refleksja nad kondycja społeczeństwa i państwa polskiego, Wydawnictwo Naukowe Instytutu Filozofii Uniwersytetu im. Adama Mickiewicza, Poznań 2013.
} 
kultura polityczna nastąpił wraz z pojawieniem się pracy Gabriela A. Almonda i Sidneya Verby pt. The Civic Culture. Political Attiudes and Democracy in Five Nations ${ }^{7}$, w której autorzy wyróżnili następujące kultury polityczne: zaściankowa ${ }^{8}$, poddańcza ${ }^{9}$ oraz uczestniczaca ${ }^{10}$. Ta ostatnia ma odpowiadać kulturom politycznym funkcjonujacym w państwach o ustroju demokratycznym. Najwyższym stadium kultury uczestniczacej według tych badaczy jest kultura obywatelska. Paradoksalnie nie utożsamiali jej $z$ racjonalistyczno-aktywistycznym modelem obywatelstwa demokratycznego, który zakłada konieczność zaangażowania obywateli w sprawy publiczne ${ }^{11}$, by mógł się zrealizować ideał demokracji substancjalnej.

Kulturę obywatelska Almond i Verba potraktowali jako końcowe stadium kultury uczestniczącej, w której zachodzi stan równowagi między aktywnościa a pasywnościa obywateli w sferze publicznej. Ponadto przypisywali oni obywatelom umiejętność zachowania równowagi pomiędzy zachowaniem racjonalnym a emocjonalnym. Założyli bowiem, że w kulturze obywatelskiej mamy do czynienia ze wszystkimi rodzajami postaw politycznych, a więc oprócz postaw uczestnictwa $\mathrm{w}$ tej kulturze obywatele przyjmuja również postawę

\footnotetext{
7 Por. G.A. Almond, S. Verba: The Civic Culture. Political Attitudes and Democracy in Five Nations, Sage, Newbury Park-London-New Delhi 1989.

8 W zaściankowej kulturze politycznej ogół społeczności nie jest zainteresowany sprawami politycznymi, a także brak jest podstawowej wiedzy na temat mechanizmów rządzenia i podejmowania decyzji politycznych. W tej kulturze elity sprawują rządy w taki sposób, aby utrwalić system polityczny przez niedokonywanie w nim żadnych zmian. Ponadto brak jest wyspecjalizowanych instytucji społecznych, politycznych, ekonomicznych czy religijnych. Najczęściej wszystkie te sfery, a więc społeczna, polityczna, ekonomiczna i religijna skoncentrowane sa w tym samym ośrodku władzy.

9 W poddańczej kulturze politycznej ogół społeczeństwa ma świadomość istnienia różnych ośrodków władzy, czasami poddaje je ocenie, aczkolwiek nawet gdy owa ocena jest negatywna, to nie angażuje się $\mathrm{w}$ przeprowadzanie jakichkolwiek zmian, by dany stan rzeczy uległ zmianie. Nie podejmuja żadnych oddolnych inicjatyw, bowiem panuje powszechny marazm i brak wiary, że cokolwiek można zmienić. W związku z powyższym w tego typu kulturze politycznej trudno dostrzec jakiekolwiek roszczenia wobec sprawujących rządy. System polityczny w omawianej kulturze politycznej funkcjonuje, bazując na poczuciu przyzwyczajenia do istniejących rządów.

${ }^{10} \mathrm{~W}$ kulturze politycznej uczestnictwa, dostrzega się zaangażowanie obywateli w sprawy polityczne. Dążą oni do poznania wszelkich mechanizmów, na mocy których sa podejmowane decyzje polityczne. Dysponując tą wiedza odczuwaja, że mają realny wpływ na podejmowane decyzje społeczne, i sa bardziej skłonni do czynnego zaangażowania się w życie publiczne.

${ }^{11}$ G.A. Almond, S. Verba: The Civic Culture, s. 339.
} 
zaściankowości i podporządkowania ${ }^{12}$. Pasywność obywateli w kulturze obywatelskiej wynika przede wszystkim $z$ faktu, że mimo iż dostrzegaja pewne niedociagnięcia ze strony rzadzacych, to powstrzymuja się od podejmowania działań, gdyż - w ich ocenie ogólny kierunek aktywności decydentów mieści się w granicach tolerancji. Innymi słowy, obywatele obdarowuja rzadzacych kredytem zaufania, by ci mieli szansę skutecznej naprawy życia w państwie. Jeśli jednak ten kredyt zostanie wyczerpany, to obywatele, dysponujac odpowiednia wiedza i kompetencjami na temat życia publicznego, moga doprowadzić do zmiany ekipy rządzącej (np. podczas wyborów) lub też wymusić na władzach zmianę polityki na danym polu decyzyjnym, jeśli coś ich mocno zirytowało (np. w sprawie podniesienia wieku emerytalnego). Według Almonda i Verby kultura obywatelska może w ten sposób funkcjonować $z$ powodu zachowania spójności $z$ polityczna struktura, to znaczy, że obywatele akceptuja demokrację jako system polityczny i jej podstawowe instytucje, a jednocześnie sa ufni wobec ludzi w ogóle, co skutkuje otwartością na najróżniejsze sprawy wspólno$\operatorname{ty}^{13}$. Zdolni są wówczas do prowadzenia dyskusji, gdyż posługują się racjonalna argumentacją zarówno w dialogu $z$ rządzącymi, jak i we wzajemnych stosunkach, czego owocem jest osiagnnięcie porozumienia $\mathrm{w}$ danej sprawie. Elity polityczne, otrzymujac wytyczne $\mathrm{w}$ pewnych ważnych dla obywateli sprawach $\mathrm{w}$ celu podjęcia sprawnego działania i w konsekwencji osiagnięcia porozumienia ${ }^{14}$, są zobligowane, by podążać za obywatelskimi wytycznymi, gdyż maja świadomość, iż kompetentny obywatel je rozliczy ze złożonych obietnic i wierności owym wytycznym, ponieważ to w końcu do niego należy ostateczna decyzja, kto będzie rządził w państwie w najbliższej przyszłości.

Amerykańscy politologowie, Almond i Verba, założyli, że prawidłowo funkcjonująca kultura obywatelska musi być współtworzona

\footnotetext{
${ }_{12}$ Ibidem, s. 30.

${ }_{13}$ Ibidem.

${ }^{14}$ P. Sekuła: Kultura polityczna a konsolidacja demokracji, Oficyna Wydawnicza AFM, Kraków 2009, s. 53.
} 
przez kompetentnego obywatela, bo wówczas system demokratyczny ma największe szanse na zachowanie stabilności ${ }^{15}$. Stworzyli zatem pewien obraz owego kompetentnego obywatela, właściwego kulturze obywatelskiej. W obrazie tym zakłada się, że posiada on przynajmniej wiedzę na temat życia publicznego, która pozwala mu uzyskać poczucie realnego, a nie fikcyjnego wpływu na politykę, a ponadto wiedza ta sprawia, że kompetentny obywatel zachowuje się lojalnie wobec systemu demokratycznego jako całości. Tym samym przez większość czasu obywatel w życiu publicznym pozostaje pasywny, gdyż wierzy, że rządzacy działają na korzyść rzadzonych. Fundamentem tego zaufania jest przekonanie, iż klasa rządząca ma świadomość, że kompetentny obywatel w każdym momencie jest zdolny podjąć działania indywidualne lub grupowe, które moga pozbawić rządzacych dotychczasowej władzy.

Owa pasywność obywatela w życiu publicznym ustanie w momencie, gdy oceni on, że akceptowany przez społeczeństwo układ wartości społeczno-politycznych jest zagrożony ${ }^{16}$. Wówczas to kompetentny obywatel porzuca swoja pasywność i domaga się również od innych współobywateli rzeczywistego zaangażowania na rzecz utrzymania stabilności ładu normatywnego i całego systemu politycznego. Staje się aktywnie działającym aktorem politycznym, który nie czeka na termin kolejnych wyborów, mających wyłonić jego reprezentantów politycznych w ośrodkach władzy. Innymi słowy, reaguje w sposób zdecydowany na wszelkie próby osłabienia struktury instytucjonalnej systemu demokratycznego.

\section{Społeczeństwo konsumpcyjne jako przyczyna zaniku kompetentnego obywatela}

We współczesnym świecie dominuja procesy globalizacyjne, które w znaczący sposób przekształcają rzeczywistość społeczną, po-

${ }_{15}$ Por. G.A. Almond, S. Verba: The Civic Culture, s. 207.

${ }^{16}$ Ibidem, s. 284. 
lityczna, ekonomiczna i kulturową. Dzisiejszy świat to przestrzeń nieustannej konsumpcji, która nigdy wcześniej nie miała tak znaczącego wpływu na rzeczywistość społeczną, w tym także polityczną. Niemniej przez konsumpcję nie należy rozumieć tylko posiadania i używania rzeczy, lecz zjawisko znacznie szerzej pojmowane, które znacząco wpływa na tożsamość jednostki, a więc i społeczeństwa. Jak zauważa Wiesław Godzic:

Tożsamości sa aktywnie konstruowane: ludzie nabywaja przedmioty i aktywności kulturowe nie po to, żeby wyrazić jakiś istniejący sens tego, kim sa. Raczej odwrotnie: kreuja sens tego, czym sa, przez to, co konsumuja. W ten sposób konsumpcja jest konsumpcja znaków i symboli - nie zaś przedmiotów ${ }^{17}$.

Konsumpcja oczywiście towarzyszyła człowiekowi od zawsze, ale wiek XXI wraz $z$ postępującymi negatywnymi skutkami globalizacji ekonomicznej sprawił, iż przybrała ona nowa formułę ${ }^{18}$. Współcześnie bowiem nie chodzi już jedynie o zaspokojenie podstawowych potrzeb człowieka, związanych $z$ zapewnieniem sobie bytu i bezpieczeństwa, lecz także o umożliwienie jednostce autoekspresji, czyli premiowane jest nastawienie na rozwój własnego „ja"19. Konsumpcjonizm zatem oddala od konstytuowania się wspólnoty, wzmacnia zaś alienację jednostek. Niweczy kanon kultury uczestnictwa obywateli w życiu publicznym.

Kanon kultury jest tym, co pozwala utrzymać i pogłębić tożsamość kulturową danego narodu lub społeczności, a jego cechą jest to, że wzorce postępowania przez nią wyznaczone stanowią dla ludzi jakiegoś kręgu imperatyw ${ }^{20}$. Jest to jednak konieczność powszechnie akceptowana, ponieważ tworzy ona wyidealizowany

\footnotetext{
17 W. Godzic: Ogladanie i inne przyjemności kultury popularnej, Rabid, Kraków 1996, s. 179.

${ }_{18}$ Por. K. Przybyszewski: Negatywność ekonomicznych procesów globalizacyjnych, „Chorzowskie Studia Polityczne" 2014, nr 8, s. 13-25.

${ }^{19}$ Por. R. Ingelhart, Wartości postmaterialne oraz przejście od wartości zwiazanych z przetrwaniem do wartości zwiazanych $z$ wyrażaniem własnego "ja", przekład T. Płudowski, w: D.J. Dalton, H.D. Klingemann (red.): Zachowania polityczne, t. 1, Wydawnictwo Naukowe PWN, Warszawa 2010, s. 28.

${ }^{20}$ M. Żardecka-Nowak: Globalizacja a kanon kultury, w: A.L. Zachariasz (red.): Narody słowiańskie wobec globalizacji, Wydawnictwo Uniwersytetu Rzeszowskiego, Rzeszów 2003, s. 103.
} 
obraz, w którym to, co złe i haniebne, zostaje pominięte ${ }^{21}$. Kanon kulturowy, jako wyidealizowany obraz, nie jest jeszcze tożsamościa sama w sobie, a jedynie poczuciem tożsamości. Kanon kulturowy przekraczający poczucie tożsamości zawiera bowiem także elementy antagonistyczne, które moga i powinny osiagnać równowagę, tzn. nie niszczyć się nawzajem ${ }^{22}$. Poczucie tożsamości określa się powszechnie jako rozpoznawanie siebie, czyli swoich doświadczeń, uczuć, przekonań, potrzeb, możliwości, umiejętności, relacji i więzi, a także jako zarówno pamiętanie, jak i zapominanie autobiografii i wydarzeńn ${ }^{23}$.

Tożsamość, a nie poczucie tożsamości kształtowane przez kanon kulturowy, wymaga pewnej sztywności. To znaczy uszanowania wspólnej przeszłości (uwzględnienie tradycji, dziedzictwa kulturowego), a więc tego, co konstytuuje daną wspólnotę, tworząc szczególny porządek wartości, który decyduje o jej swoistości, niepowtarzalności i własnym obliczu. Wspólna przeszłość powołuje do życia przeświadczenie o istnieniu „my” w odniesieniu do „onych”, którzy nie partycypuja w tej samej rzeczywistości, bo nie dysponuja tym samym doświadczeniem. Jednocześnie oprócz owej sztywności tożsamość kulturowa, czyli „my”, wyróżnia się także otwarciem ku przyszłości, a więc cechuje się również pewną elastycznościa pozwalająca na unowocześnienie. W tym kontekście tożsamość, a nie poczucie tożsamości, oznacza zachowanie pewnej ciagłości, mimo dokonujących się zmian.

Tożsamość jednostki nie ma zatem charakteru statycznego, danego jako „coś” wiecznego w momencie narodzin w danej kulturze, lecz jawi się jako permanentny, dynamiczny proces, w którym jednostka cały czas musi siebie określać wobec zewnętrznego świata, by tworzyć swój wewnętrzny świat, a następnie - ponownie umiejscawiać siebie w świecie zewnętrznym. Podstawowe trzy pytania, które sobie stawia, kształtując własną tożsamość to: „Kim

\footnotetext{
${ }^{21}$ Ibidem, s. 104.

${ }^{22}$ Ibidem.

${ }^{23}$ H. Szymańska: Globalizacja a zagubione poczucie tożsamości i dziedzictwo kulturowe, „Studia Etnograficzne i Antropologiczne” 2014, nr 14, s. 242.
} 
jestem?”, „Ku czemu zmierzam?”, „Kim chcę być?”. Skoro tożsamość jednostki nie ma charakteru statycznego, to różne czynniki oraz uwarunkowania moga wpływać na jej zmianę. Podstawowym czynnikiem kształtującym ową tożsamość w określonym społeczeństwie jest proces socjalizacji, w którym przekazywane sa pewne struktury normatywne $z$ obowiąujacego kanonu kulturowego, a więc np.: $z$ tradycji czy $z$ pamięci zbiorowej. Przyswojenie sobie przez jednostkę określonego kanonu kulturowego wytwarza u niej swoisty pomost między nią samą a system społecznym. Procesy globalizacyjne znaczaco wpływaja na obowiąujące kanony kulturowe, tym samym zmieniaja, tożsamość jednostki oraz tożsamość kulturowa danej społeczności. Kształt owych procesów odpowiada założeniom doktryny zwanej neoliberalizmem.

Neoliberalizm to doktryna polityczno-społeczna zorientowana na rynki kapitałowe, prywatyzację i umowy handlowe ${ }^{24}$. Podstawowym założeniem przyjmowanym przez neoliberalizm jest to, że rynek stanowi najefektywniejszy mechanizm optymalnej alokacji zasobów, czyli zapewnia najwyższy poziom zaspokajania potrzeb. Założenie to jest konsekwencja przyjętych wcześniej przez neoliberalizm prawideł, mających formę aksjomatów: 1) indywidualny wybór dokonywany na rynkach jest w zasadzie lepszy i przynosi korzystniejsze wyniki niż jakikolwiek inny wybór; 2) regulacje rządowe w sektorze prywatnym powinny zostać zaniechane na rzecz samoregulacji i większej konkurencji; 3) sektor publiczny powinien zostać skomercjalizowany, a państwowe przedsiębiorstwa sprywatyzowane; 4) podatki powinny być tak niskie, jak to tylko możliwe, przy jednocześnie obowiąującej zasadzie „użytkownik płaci” za wiele usług świadczonych przez państwo (rząd); 5) bariery w handlu międzynarodowym powinny zostać wyeliminowane; 6) reguły rynku powinny być zastosowane do wszystkich dóbr publicznych, czyli do edukacji, zdrowia, kultury, ochrony środowiska itp. ${ }^{25}$

\footnotetext{
${ }^{24}$ A. Zawojska: Liberalizm, neoliberalizm, wolność ekonomiczna i polityczna a rozwój gospodarczy kraju, „Zeszyty Naukowe SGGW”, seria „Ekonomika i Organizacja Gospodarki Żywnościowej" 2006, nr 58, s. 6.

${ }_{25}$ Por. D. Mc Knight: Beynod Right and Left. New Politics and the Culture War, Allen \& Unwin, Sydney 2005, cyt. za: A. Zawojska: Liberalizm, neoliberalizm, wolność ekonomiczna..., s. 7.
} 
Szczególne ostatni aksjomat neoliberalizmu nie pozostawia złudzeń co do tego, że wszyscy mamy stać się przede wszystkim konsumentami dóbr dostarczanych przez rynek, a zatem zwolennicy globalizmu dążć będa, by powszechna stała się tzw. tożsamość konsumencka. Wzmacnianie jej jest możliwe w warunkach ujednoliconego systemu bankowego, handlu, rachunku ekonomicznego, norm technicznych, wymogów odnośnie do jakości produktów, unifikacji środków płatniczych itp., a więc w wyniku daleko posuniętej normalizacji i standaryzacji $\mathrm{w}$ wymiarze światowym ${ }^{26}$. W tej perspektywie „wolny rynek” oznacza po prostu rynek konsumencki.

Zaznaczyć należy, że od konsumenta nie oczekuje się postaw obywatelskich, dlatego też według neoliberalizmu jednostka-konsument nie powinna myśleć w kategoriach „my” i dobra wspólnego, lecz w kategoriach „ja” i własnych potrzeb. Obywatele w świecie konsumpcjonizmu zatracają troskę o dobro ogółu bądź o dobro wspólne. Dlatego też grupy społeczne sa zastępowane przez „roje” konsumentów; miejsce wspólnoty społeczeństwa tradycyjnego zajmuje „pole społeczne”, a dokładniej szereg wytoczonych pól (religijnych, politycznych, prawnych, naukowych, artystycznych, akademickich, socjologicznych etc. $)^{27}$.

Idea roju zakłada organizm złożony i precyzyjnie zarządzany, a także zdolny do bezrefleksyjnego wykonywania powierzonych rozkazów. Wielkim międzynarodowym korporacjom łatwiej jest sterować polami społecznymi, otoczonymi przez roje konsumentów, aniżeli zapanować nad tradycyjną wspólnota polityczną ${ }^{28}$. Na przykład uniwersytet przestaje być wspólnota akademicka, lecz staje się przedsiębiorstwem, mającym do zaoferowania studentom określony produkt, a ci w takim układzie stają się tylko konsumentami.

\footnotetext{
${ }^{26}$ W. Sztumski: Globalizacja-lęk przed nieznanym, ryzyko nadziei, w: A.L. Zachariasz (red.): Narody słowiańskie wobec globalizacji, Wydawnictwo Uniwersytetu Rzeszowskiego, Rzeszów 2003, s. 64.

${ }^{27}$ Terminy „rój konsumentów” oraz „pola społeczne” wprowadził Pierre Bourdieu (por. P. Boudieu, L.J.D. Wacquant: Zaproszenie do socjologii refleksyjnej, przekład A. Sawisz, Oficyna Naukowa, Warszawa 2008, s. 78).

${ }^{28}$ M. Maciejczak: Tożsamość a rozumienie siebie, „Studia Philosophiae Christianae” 2011, nr 1 , s. 103 .
} 
Konsumeryzm $z$ jego kultura i etyką w gruncie rzeczy zabija wartości wspólnotowe i kulturową różnorodność świata ${ }^{29}$. Można zatem powiedzieć, że neoliberalizm ma na celu eliminację wszelkiej polityki i podporządkowanie jej zasadom „dzikiego” wolnego rynku. Jak zauważa Kazimierz Krzysztofek, niechęć do rynku i konsumpcji kultury jako regulatora tożsamości wypływa po części $z$ utraty kontroli elit narodowych nad procesami kultury, niemożności zapanowania nad tym, jakie wartości w niej powinny być zachowane, a jakie elementy - ulec zmianie ${ }^{30}$. W ten oto sposób coraz powszechniejszy staje się trend, iż obywatele stając się konsumentami, zatracaja podstawowa wiedzę na temat mechanizmów politycznych. Polityka jest dla nich czymś abstrakcyjnym i dalekim od ich życia, dlatego też popadaja w nihilizm polityczny.

Sfera konsumpcji staje się terenem, na który oddziałuje polityka. Wszelkie programy przedstawiane w kampaniach wyborczych $\mathrm{w}$ dużym stopniu skoncentrowane sa na poprawianiu sytuacji konsumentów. Ponadto nawet te majace $z$ założenia wspomagać sytuacje rodzin, jak np. „Rodzina 500 plus”, legitymizowane sa ekonomicznie, tj. maja przynieść wzrost wydatków konsumpcyjnych. Te $z$ kolei traktowane sa jako najlepsza inwestycja w ochronę miejsc pracy. Podnosi się, że zmniejszenie zakupów to główna przeszkoda wzrostu koniunktury gospodarczej. Podejmowane sa więc działania polityczne, by pobudzić potrzeby konsumpcyjne, skutkujące wzrostem zakupów (dopłaty do wybranych dóbr konsumpcyjnych, np. w Niemczech do samochodów). W ten sposób dochodzi do stymulowania popytu. W rezultacie brana jest pod uwage jedynie teoria racjonalności kalkulatywnej konsumentów, a nie inne, długofalowe czynniki dynamizujące zmiany społeczne i kulturowe. Obecna polityka ukierunkowana jest zatem na stwarzanie sztucznych potrzeb.

\footnotetext{
${ }^{29}$ E. Rekłajtis: Społeczne warunki globalizacji konstruktywnej, w: J. Zdanowski (red.): Kultury pozaeuropejskie i globalizacja. Zdarzenia, Wydawnictwo Elipsa, Warszawa 2000, s. 169.

${ }^{30}$ K. Krzysztofek: Kulturowa ścieżka globalizacji, w: M. Pietraś (red.): Oblicza globalizacji, Wydawnictwo Uniwersytetu Marii Curie-Skłodowskiej, Lublin 2002, s. 134.
} 
Podobnie postępuje klasa polityczna, która to swoje programy traktuje w kategoriach towaru, obywatela zaś w kategoriach klienta, konsumenta. Bardziej zwraca się uwage na to, by obywatel zwrócił uwage na „opakowanie”, a nie na treść danego programu politycznego. Stosowana podczas wyborów demagogię związana $z$ prezentowaniem programów politycznych zwykło się potocznie nazywać „kiełbasa wyborcza”. Powiąane jest to $z$ tzw. mediatyzacja polityki, czyli zanikiem służebnej roli mediów, tzw. czwartej władzy, która miała pełnić funkcję kontrolna dla pozostałych trzech władz: ustawodawczej, wykonawczej i sądowniczej. Albowiem w pogoni za sensacja, która uznano za najlepiej sprzedawalny towar, również media poddały się pragmatyce neoliberalnej. W konsekwencji, jak zauważa Jean Baudrillad, żyjemy dzisiaj poza sensem, bo

[...] środki przekazu przepędzają precz zarówno sens, jak i bezsens, manipulują we wszystkich możliwych sensach, nikt nie może poddać tego procesu kontroli, sa nośnikiem symulacji, będącej immanentną właściwościa systemu i zarazem symulacji dla tego systemu zgubnej $[\ldots]^{31}$.

Świat polityki i mediów na tyle zbliżył się do siebie, że wręcz powoli nabrał charakteru symbiozy, w wyniku której zatraca się autentyczność rzeczywistości politycznej ${ }^{32}$. W świecie tym znajduje zastosowanie retoryka polityczna nowego typu, która zorientowana jest bardziej na obraz, metaforę i emocje aniżeli na racjonalna argumentację ${ }^{33}$.

Ponadto na scenie politycznej zaobserwować można również zjawisko „konsumpcyjnego mandatu poselskiego”, czyli swobodne przechodzenie reprezentantów społeczeństwa $z$ jednej partii do drugiej, często o całkowicie różnych fundamentach aksjologicz-

\footnotetext{
${ }^{31}$ J. Baudrillard: O uwodzeniu, przekład J. Margański, Wydawnictwo Sic!, Warszawa 2005, s. $55-56$.

${ }^{32}$ Por. K. Przybyszewski: Mediale Manipulationen im Kontext der Mediatisierung von Politik, „Lingua and Communitas” 2013, nr 23, s. 79-91.

${ }_{33}$ B. Dobek-Ostrowska, R. Wiszniowski: Teoria komunikowania publicznego i politycznego. Wprowadzenie, Wydawnictwo Astrum, Warszawa 2001, s. 131.
} 
nych w wymiarze moralnym, społeczno-politycznym i ekonomicznym $\mathrm{w}$ trakcie wypełniania przez nich mandatu poselskiego. Zwykle to zjawisko nazywamy korupcja polityczna dla partykularnych celów „partii kupującej”. Nie dziwi więc brak zaufania obywateli dla klasy politycznej, wszystko bowiem odbywa się poza wola wyborcy, który to oddał swój głos na danego kandydata $z$ ramienia określonego ugrupowania.

Tego typu działania w sferze politycznej również nie sprzyjaja wzmacnianiu kultury obywatelskiej społeczeństwa. Są ewidentnym przejawem postpolityki.

\section{Zakończenie}

Chociaż we współczesnym świecie istnieje wiele świadectw niszczenia kultury obywatelskiej przez ogromny wzrost konsumpcjonizmu, to jednak stosunki społeczne oparte na jego gruncie, jak zauważa Michael Schudson, moga też tę kulturę wspieraćc ${ }^{34}$. Podejmując refleksję, dlaczego bycie obywatelem jest wartościowane pozytywnie, a bycie konsumentem pejoratywnie, badacz ten słusznie zauważa, że pewne postawy konsumenckie moga wspierać życie obywatelskie, a tym samym przyczyniać się do wzmocnienia kultury obywatelskiej w ustroju demokratycznym. Ponadto wskazuje, iż można mieć do czynienia zarówno $z$ dobrym, jak i złym obywatelem. Dobry to ten, który nie koncentruje się wyłącznie na przysługujacych mu prawach i przywilejach, ale również stara się realizować powinności i obowiązki wpisane w rolę bycia obywatelem. Tak samo będzie $z$ konsumentem.

Dobrego konsumenta Michael Schudson nazywa „konsumentem $z$ wyszukanym smakiem"35. Jest to ktoś, kto świadomie steruje swoimi postawami konsumenckimi, próbując za ich pomoca

\footnotetext{
${ }^{34}$ M. Schudson: Citizens, Consumers and the Good Society, „Annals of the American Academy of Political and Social Science" 2007, t. 611, s. 236.

${ }^{35}$ Ibidem, s. 237.
} 
wywierać określony wpływ na politykę. Celowo może bojkotować towary producentów, którzy czerpią zyski z niewolniczej pracy innych ludzi, wymuszając $\mathrm{w}$ ten sposób zmianę polityki danej firmy. $Z$ kolei $z$ rozmysłem nabywa towary rodzimego producenta, aby wspierać gospodarkę narodową społeczeństwa, którego jest członkiem. Skłonny jest również wspierać zakupami te firmy, które znacząco są zaangażowane w różne prospołeczne akcje, na przykład w ochronę środowiska naturalnego. Ma też świadomość stosowanych socjotechnik rynkowych, takich jak np. podwyższanie cen przez manipulację asortymentem towarów i rozbudowanym aparatem pośrednictwa handlowego, a także powodowanie przez producentów sztucznego zużycia danego produktu ${ }^{36}$. Dysponuje też wiedzą o nadużyciach reklamy i sterowaniu gustami za pomoca różnego rodzaju technik psychologicznych. Innymi słowy, potrafi przeciwstawić się manipulacji rynkowej. Oznacza to, że czasami musiałby więcej zapłacić za dany towar bądź usługę. Tego typu postawa jest zwana „konsumeryzmem politycznym” i można ja faktycznie traktować jako zaangażowanie się nie tylko w troskę o dobro własne, ale również w dobro ogółu.

\footnotetext{
${ }^{36}$ Techniki manipulacji asortymentem towarów sa różnorodne. Do najbardziej znanych należy posługiwanie się hasłem „promocja”. Technika ta pomaga sprzedawcy pozbyć się produktów niechodliwych oraz niesprawdzonych przez klienta, których ten nie zamierzał kupić. Chodzi tu o stworzenie $\mathrm{w}$ kliencie poczucia, że kupuje lepszy produkt $\mathrm{w}$ promocji niż ten, który zamierzał kupić wcześniej, choć w rzeczywistości płaci za niego drożej, niż gdyby nabył sprawdzony przez siebie produkt niebędacy aktualnie w promocji. Innym przykładem podwyższania cen za pomoca manipulacji asortymentem towarów jest tzw. zasada złotego środka. Polega ona na ustawieniu na półce sklepowej produktów tego samego rodzaju o różnych cenach w kolejności od bardzo taniego, przez nieco droższy, aż po najdroższy. Jest duże prawdopodobieństwo, że większość klientów zdecyduje się na produkt pomiędzy tanim a najdroższym. Zrobią tak dlatego, że nie chca mieć najgorszego produktu, a zarazem nie stać ich na najdroższy, sięgną więc po „złoty środek”, mimo że ten produkt jest takiej samej jakości, co ten najtańszy i najdroższy, a wszystkie te trzy produkty równie dobrze można by było sprzedać po tej samej cenie, co ten najtańszy. W konsekwencji klient płaci więcej, niż powinien za chęć przynależności do „klasy średniej”. Manipulowanie zużyciem produktów najbardziej jest widoczne na rynku sprzętu elektronicznego, gdzie zepsucie sie jednego elementu danego urządzenia powoduje konieczność zakupu nowego egzemplarza, jako że naprawa takiego sprzętu jest wyżej wyceniana od kupna nowego. Zdarza się też, że zużywalna część danego sprzętu ma wyższą cenę niż cały ów sprzęt. Tak bywa na przykład w przypadku drukarek komputerowych: często kupno nowej wraz z tonerem kosztuje mniej aniżeli zakup samego do niej tonera.
} 
Problemem jednak jest to, że taki konsument musi orientować się i posiadać wiedzę na temat funkcjonowania globalnej gospodarki wolnorynkowej, sposobu produkcji towarów nabywanych, jak też metod manipulacji rynkowej etc. Tymczasem w większości przypadków nie posiada on pogłębionych informacji, a nawet jeśli nimi dysponuje, to nie reaguje, lecz kieruje się cena oraz chęcia sprawienia sobie krótkotrwałej przyjemności. Nie stawia sobie też pytań o to, czy jego wybory konsumenckie sa moralne i czy przyczyniaja się one do dobra ogółu społeczeństwa.

Należy zwrócić uwagę na inny jeszcze aspekt współczesnego konsumpcjonizmu. Dawniej konsumpcja wiąała się $z$ relacja interpersonalna między klientem a sprzedawca, na niej również budowano więzi społeczne. Obecnie obserwujemy depersonalizację wymiany rynkowej, coraz częściej bowiem korzysta się ze zdobyczy techniki (zwłaszcza Internetu), która umożliwia dokonywanie zakupów bez konieczności wychodzenia $z$ domu.

Podsumowując, powtórzmy: kultura obywatelska zanika, gdyż nowe społeczeństwo konsumpcyjne, powstające na bazie doktryny neoliberalnej, jest pozbawione „kompetentnego obywatela”, a także „konsumenta $z$ wyszukanym smakiem”. 